\title{
Syntrophobacter sulfatireducens sp. nov., a novel syntrophic, propionate-oxidizing bacterium isolated from UASB reactors
}

\author{
Correspondence \\ Xiuzhu Dong \\ dongxz@sun.im.ac.cn
}

\author{
Shuangya Chen, ${ }^{1,2}$ Xiaoli Liu ${ }^{1}$ and Xiuzhu Dong ${ }^{1}$
}

State Key Laboratory of Microbial Resources, Institute of Microbiology, Chinese Academy of Sciences ${ }^{1}$ and Graduate School of the Chinese Academy of Sciences ${ }^{2}$, Beijing 100080, PR China

Two obligate anaerobes, TB8106 ${ }^{\top}$ and $\mathrm{WZH410,} \mathrm{which} \mathrm{degraded} \mathrm{propionate} \mathrm{in} \mathrm{syntrophic}$ association with methanogens, were isolated from two upflow anaerobic sludge blanket reactors, one treating brewery wastewater and the other bean curd wastewater. The strains were Gramnegative, non-spore-forming and non-motile. Cells were egg-shaped, with a size of $1 \cdot 0-1 \cdot 3 \times 1 \cdot 8-2 \cdot 2 \mu \mathrm{m}$. Growth was observed at $20-48{ }^{\circ} \mathrm{C}$ and $\mathrm{pH} 6 \cdot 2-8 \cdot 8$. Both strains converted propionate to acetate and methane in co-culture with methanogens, and grew on propionate plus sulfate in pure culture, with a doubling time of $52-55 \mathrm{~h}$ at $37^{\circ} \mathrm{C}$. Sulfate and thiosulfate both served as electron acceptors for propionate degradation. The DNA G $+\mathrm{C}$ contents of the two strains were 58.5 and 58.7 mol\%, respectively. Phylogenetic analysis based on $16 \mathrm{~S}$ rRNA gene sequences revealed that the strains were closely related to a propionate-oxidizing syntrophic bacterium, Syntrophobacter fumaroxidans DSM $10017^{\top}$ (94.7\% similarity). However, the novel strains could not ferment fumarate, and grew at a more alkaline $\mathrm{pH}$ range than Syntrophobacter fumaroxidans. Moreover, the novel isolates had obviously higher growth rates on propionate plus sulfate $\left(0 \cdot 12\right.$ day $\left.^{-1}\right)$ than Syntrophobacter fumaroxidans DSM $10017^{\top}$ $\left(0.024\right.$ day $\left.^{-1}\right)$. Therefore, a novel species, Syntrophobacter sulfatireducens sp. nov., is proposed, with strain $\operatorname{TB} 106^{\top}\left(=\right.$ AS $1.5016^{\top}=$ DSM $\left.16706^{\top}\right)$ as the type strain.
In methanogenic environments, complex organic matter is degraded completely to $\mathrm{CO}_{2}$ and $\mathrm{CH}_{4}$ by the association of several trophic micro-organisms (Zehnder, 1978). Propionate, one of the central intermediates in this process, is further degraded by the combined action of acetogenic bacteria and methanogenic archaea, due to the unfavourable energetics under standard thermodynamics. The methanogens make propionate oxidation energetically feasible by keeping the concentration of the products $\mathrm{H}_{2}$ and/or formate extremely low (Stams, 1994; Schink, 1997). So far, seven syntrophic propionate-oxidizing bacterial species have been described. The four mesophilic species form a cluster within the Gram-negative $\delta$-subclass of the Proteobacteria, closely related to the mesophilic sulfate reducers.

Published online ahead of print on 14 January 2005 as DOI 10.1099/ ijs.0.63565-0.

Abbreviation: UASB, upflow anaerobic sludge blanket.

The GenBank/EMBL/DDBJ accession number for the 16S rRNA gene sequence of Syntrophobacter sulfatireducens TB8106 ${ }^{\top}$ is AY651787.

A transmission electron micrograph of a cell of Syntrophobacter sulfatireducens $\mathrm{TB} 106^{\top}$ is available as supplementary material in IJSEM Online.
They are Syntrophobacter wolinii (Boone \& Bryant, 1980; Wallrabenstein et al., 1994), Syntrophobacter fumaroxidans (Harmsen et al., 1998), Syntrophobacter pfennigii (Wallrabenstein et al., 1995) and Smithella propionica (Liu et al., 1999). Members of the genus Syntrophobacter can use sulfate as an electron acceptor and oxidize propionate via the methylmalonyl CoA pathway (Harmsen et al., 1993; Houwen et al., 1990; Plugge et al., 1993), whereas Smithella propionica, which grows axenically on crotonate, uses a six-carbon-intermediate pathway to oxidize propionate (Liu et al., 1999; de Bok et al., 2001). Unlike the mesophilic species, the three described thermophilic propionateoxidizing species are all Gram-positive, spore-forming bacteria (Nilsen et al., 1996; Imachi et al., 2002; Plugge et al., 2001). In this study, we describe two novel mesophilic syntrophic propionate-oxidizing strains, TB8106 ${ }^{\mathrm{T}}$ and WZH410. Phylogenetic analysis indicates that both strains are members of the genus Syntrophobacter. However, they are not closely related to strains of recognized Syntrophobacter species.

Strains TB8106 $^{\mathrm{T}}$ and WZH410 were isolated from the granular sludge of two mesophilic upflow anaerobic sludge blanket (UASB) reactors, one treating brewery wastewater 
in Tsinghua University and the other treating bean curd wastewater in Wangzhihe bean curd manufactory (Beijing, China). Methanospirillum hungatei DSM $864^{\mathrm{T}}$ and Syntrophobacter fumaroxidans DSM $10017^{\mathrm{T}}$ were kindly provided by $\mathrm{Dr}$ Alfons Stams, Department of Microbiology, Wageningen University, The Netherlands.

A pre-reduced basal medium was used as described by Stams et al. (1992), and yeast extract $(0.02 \%, \mathrm{w} / \mathrm{v})$ and tryptone $(0.02 \%, w / v)$ were added to stimulate growth. Routine cultivation was in anaerobic tubes $(18 \times 180 \mathrm{~mm})$, sealed with butyl rubber stoppers. A gaseous atmosphere of $\mathrm{N}_{2} / \mathrm{CO}_{2}\left(80: 20,1 \cdot 01 \times 10^{5} \mathrm{~Pa}\right)$ was used, except that $\mathrm{H}_{2} /$ $\mathrm{CO}_{2}\left(80: 20,1.25 \times 10^{5} \mathrm{~Pa}\right)$ was used for cultivating methanogens. All inoculations and transfers were done with syringes and needles, and all cultures were incubated at $37^{\circ} \mathrm{C}$ in the dark. For the isolation of co-cultures, direct serial dilution and the Hungate roll-tube technique (Hungate, 1969) were used, with $20 \mathrm{mM}$ propionate as the sole carbon source. For the isolation of pure cultures of propionate-degrading bacteria, $20 \mathrm{mM}$ propionate plus $20 \mathrm{mM}$ sulfate were used. The purity of the strains in coculture and pure culture was checked by microscopic examination, and by colony formation on solid media, as well as by the absence of growth in rich medium such as tryptone-peptone-yeast extract-glucose liquid medium (Holdeman et al., 1977).

Cell morphology was examined under a light microscope (Olympus BH-2) and an electron microscope (Hitachi H600 A). For electron microscopy studies, cells were negatively stained with uranyl acetate.

In order to determine the optimum growth conditions for strains TB $8106^{\mathrm{T}}$ and WZH410, the basal medium with $20 \mathrm{mM}$ propionate plus $20 \mathrm{mM}$ sulfate and a $10 \%$ inoculum were used. Growth at various $\mathrm{pH}$ values was determined in media adjusted with $1 \mathrm{M} \mathrm{HCl}$ or $\mathrm{NaOH}$. Temperature profiles were determined by using a water bath (Guangming Medical Instrument Plant, Beijing) at 15 to $55^{\circ} \mathrm{C}$, at $1{ }^{\circ} \mathrm{C}$ intervals $(\mathrm{pH} 7 \cdot 5)$. To determine the $\mathrm{NaCl}$ tolerance, $0-1000 \mathrm{mM} \mathrm{NaCl}$ was added to the medium. The generation time of the strains was determined by monitoring the $\mathrm{OD}_{600}$ of the culture at $37^{\circ} \mathrm{C}$ at 1-day intervals for up to 60 days. Growth under the various conditions given above was determined by monitoring the $\mathrm{OD}_{600}$ after cultivation for up to 60 days.

To determine the substrate range of the strains in pure culture and in co-culture with methanogens, sterilized substrates were added to the basal medium to a final concentration of $20 \mathrm{mM}$ (unless indicated otherwise), instead of propionate. To determine the electron acceptors for propionate degradation of the methanogen-free culture, each of the tested compounds $(20 \mathrm{mM})$ was added to the propionate medium. After inoculation, the cultures were incubated for up to 90 days. Utilization of substrates by the strains was determined by monitoring the $\mathrm{OD}_{600}$ of the culture, substrate depletion and product formation. Fatty acids and $\mathrm{CH}_{4}$ were detected by using a gas chromatograph (GC-14B; Shimadzu), as described previously (Chen \& Dong, 2004). All tests were performed in duplicate with a $10 \%$ inoculum.

Genomic DNA was extracted and purified from strains TB8106 ${ }^{\mathrm{T}}$ and WZH410 grown on propionate plus sulfate, as described by Marmur (1961). The mol\% G+C content of DNA was determined by the thermal denaturation method (Marmur \& Doty, 1962), by using a DU800 spectrophotometer (Beckman) with Escherichia coli K-12 as the reference. The 16S rRNA gene was amplified and sequenced according to Chen \& Dong (2004). Sequencing was performed by Sangon Biological Engineering Technology Service, Shanghai, China, using ABI PRISM Big Dye Terminator cycle sequencing ready reaction kits (Perkin Elmer) and an ABI PRISM 377XL DNA sequencer. The 16S rRNA gene sequence of strain TB8106 ${ }^{\mathrm{T}}$ was submitted to GenBank and EMBL to search for similar sequences using the BLAST algorithm. The best matching sequences were retrieved from the database and aligned, and similarity analysis was performed using the CLUSTAL_X program (Thompson et al., 1997). Phylogenetic trees were constructed by using the neighbour-joining, maximumlikelihood and maximum-parsimony methods, implemented in the MEGA 2 program (Kumar et al., 2001) and the PHYLIP package (Felsenstein, 1993). The topologies of the resultant tree were evaluated by bootstrap analysis (Felsenstein, 1985), based on 1000 resamplings.

DNA-DNA hybridization was performed at $73{ }^{\circ} \mathrm{C}$ on the basis of DNA-DNA liquid reassociation rate (De Ley et al., 1970), using a DU800 spectrophotometer (Beckman).

Propionate-degrading methanogenic enrichments were developed from anaerobic digester sludge by diluting the sludge at a ratio of $1: 10$ with the basal medium plus $20 \mathrm{mM}$ sodium propionate. After 3 weeks of incubation at $37^{\circ} \mathrm{C}$, the enriched cultures degraded propionate and produced large amounts of $\mathrm{CH}_{4}$. The enrichments were subcultured six times, and then the roll-tube technique was applied with propionate-containing agar medium. After incubation for 10 weeks, colonies were visible in the roll tubes. Large colonies at dilutions of $10^{-4}$ and $10^{-5}$ that emitted green fluorescence at a wavelength of $420 \mathrm{~nm}$ were picked and inoculated into the propionate medium. This roll-tube procedure was repeated several times over a period of 2 years, until two co-cultures that produced methane from propionate were obtained. The co-cultures consisted of two kinds of cell with different morphologies: one was eggshaped and the other resembled Methanobacterium formicicum cells. Colonies of the co-cultures were yellowish, circular and $1 \cdot 5-2 \cdot 0 \mathrm{~mm}$ in diameter, and emitted green fluorescence at $420 \mathrm{~nm}$ after 10 weeks of incubation. The propionate oxidizers were further purified by inoculating the co-culture onto medium containing $20 \mathrm{mM}$ propionate plus $20 \mathrm{mM}$ sulfate; $10 \mathrm{mM}$ 2-bromoethane sulfonate was also added to inhibit the methanogen. After being subcultured 12 times on this medium, monocultures 
designated as strains TB8106 ${ }^{\mathrm{T}}$ and WZH410 were obtained. Hardly any growth of the strains as a pure culture was observed on solid medium, and propionate could not be degraded in the absence of sulfate, whereas propionate was degraded to acetate and $\mathrm{CH}_{4}$ in an artificially constructed co-culture with Methanospirillum hungatei DSM $864^{\mathrm{T}}$ after 50-60 days.

Cells of strains $\mathrm{TB}^{2} 106^{\mathrm{T}}$ and WZH410 were non-motile, Gram-negative, egg-shaped, and $1 \cdot 0-1 \cdot 3 \times 1 \cdot 8-2 \cdot 2 \mu \mathrm{m}$ in size (see Supplementary Figure in IJSEM Online). Spore formation was never observed. The strains were strictly anaerobic; no growth occurred when exposed to air. The temperature range for growth was $20-48^{\circ} \mathrm{C}$, with optimum growth occurring at $37^{\circ} \mathrm{C}$. The $\mathrm{pH}$ range for growth was $6 \cdot 2-8 \cdot 8$, with optimum growth occurring at $\mathrm{pH} 7 \cdot 0-7 \cdot 6$. $\mathrm{NaCl}$ was tolerated up to a concentration of $100 \mathrm{mM}$ (best growth occurred at concentrations below $50 \mathrm{mM}$ ). Addition of $0.02 \%$ yeast extract and tryptone stimulated, but was not necessary for, growth. In pure culture on propionate plus sulfate, $20 \mathrm{mM}$ propionate was oxidized to $20 \mathrm{mM}$ acetate within $12-15$ days. The doubling time of strain TB8106 ${ }^{\mathrm{T}}$ was $52-55 \mathrm{~h}$ at $37^{\circ} \mathrm{C}$, and the growth rate was approximately $0 \cdot 12$ day $^{-1}$. The growth yield of strain $\mathrm{TB}^{2} 106^{\mathrm{T}}$ on propionate plus sulfate was $3 \cdot 3 \mathrm{~g}$ dry weight (mol propionate) $)^{-1}$.

Sulfate and thiosulfate were utilized as electron acceptors for propionate oxidation, but not sulfur, nitrate or fumarate. Strain TB8106 ${ }^{\mathrm{T}}$ utilized sulfite, whereas WZH410 did not. Both strains fermented pyruvate in pure culture. The following substrates were not used in either pure or coculture: $\mathrm{H}_{2} / \mathrm{CO}_{2}(80: 20, \mathrm{v} / \mathrm{v})$, formate, $\mathrm{H}_{2}$ plus fumarate, formate plus fumarate, acetate, butyrate, crotonate, succinate, fumarate, oxaloacetate, malate, citrate, malonic acid, glutarate $(10 \mathrm{mM})$, alanine $(10 \mathrm{mM})$, glycine $(10 \mathrm{mM})$, asparagine $(10 \mathrm{mM})$, benzoate $(10 \mathrm{mM})$, methanol, ethanol, 1-propanol, 1-butanol, glucose $(10 \mathrm{mM})$, fructose $(10 \mathrm{mM})$, xylose $(10 \mathrm{mM})$ and arabinose $(10 \mathrm{mM})$. Propionate was the sole substrate for the co-culture.

The $\mathrm{G}+\mathrm{C}$ contents of the genomic DNA of strains TB8106 ${ }^{\mathrm{T}}$ and WZH410 were $58 \cdot 5$ and $58 \cdot 7 \mathrm{~mol} \%$, respectively. The partial $16 \mathrm{~S}$ rRNA gene sequence (500 bp) similarity between strains $\mathrm{TB}^{2} 106^{\mathrm{T}}$ and WZH410 was $99 \cdot 94 \%$, indicating that they belonged to the same species.

To ascertain the phylogenetic position of strain TB8106 ${ }^{\mathrm{T}}$, the complete 16S rRNA gene sequence (1553 bp) was compared with the most similar sequences retrieved from GenBank. On the basis of a consensus $1361 \mathrm{bp}$ of the $16 \mathrm{~S}$ rRNA gene sequence, a phylogenetic tree (Fig. 1), rooted with E. coli ATCC $11775^{\mathrm{T}}$, was constructed. The tree clearly showed that strain $\mathrm{TB} 8106^{\mathrm{T}}$ clustered within the genus Syntrophobacter, in the $\delta$-subclass of the Proteobacteria, and was most closely related to strain HP1.1 (Zellner et al., 1996) ( $99 \cdot 2 \%$ similarity), a highly purified propionate-degrading culture, and Syntrophobacter fumaroxidans DSM $10017^{\mathrm{T}}$ (94.7\% similarity) and Syntrophobacter pfennigii DSM $10092^{\mathrm{T}}$ (94.6\% similarity).

Strains $\mathrm{TB}^{2} 106^{\mathrm{T}}$ and WZH410 resembled the syntrophic, propionate-oxidizing species Syntrophobacter fumaroxidans, Syntrophobacter pfennigii and Syntrophobacter wolinii in that growth occurred on propionate in co-culture with methanogens and sulfate reduction was observed in pure culture. However, distinct differences in phenotypic characteristics were observed (Table 1). In monoculture, Syntrophobacter wolinii and Syntrophobacter fumaroxidans both fermented fumarate, and Syntrophobacter fumaroxidans also utilized fumarate as an electron acceptor for propionate oxidation. Syntrophobacter pfennigii utilized lactate not only in

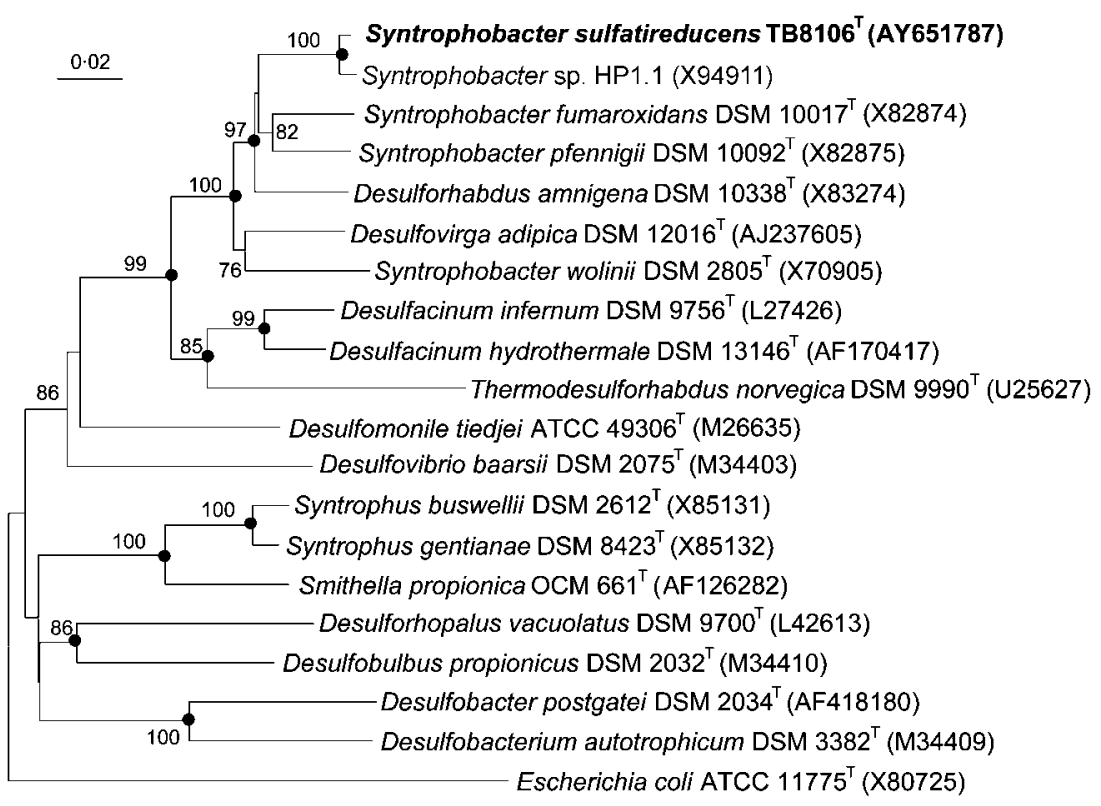

Fig. 1. Phylogenetic dendrogram of Syntrophobacter sulfatireducens TB8106 ${ }^{\top}$ and related species based on 16S rRNA gene sequence similarity. The tree was rooted with E. coli ATCC $11775^{\top}$ and was constructed using the neighbour-joining method. Solid circles indicate that the corresponding nodes (groups) were also recovered using maximum-likelihood and maximum-parsimony methods. Numbers at nodes represent percentage levels of bootstrap support, based on a neighbour-joining analysis of 1000 resampled data sets. GenBank accession numbers of $16 \mathrm{~S}$ rRNA sequences are given in parentheses. Bar, $2 \%$ sequence divergence. 
Table 1. Characteristics that can be used to differentiate Syntrophobacter sulfatireducens TB8106 $^{\top}$ from other species of the genus Syntrophobacter

Species/strains: 1, Syntrophobacter sulfatireducens TB8106 ${ }^{\mathrm{T}}$; 2, Syntrophobacter strain HP1.1 (data from Zellner et al., 1996); 3, Syntrophobacter fumaroxidans DSM $10017^{\mathrm{T}}$ (Harmsen et al., 1998); 4, Syntrophobacter pfennigii DSM 10092 ${ }^{\mathrm{T}}$ (Wallrabenstein et al., 1995); 5, Syntrophobacter wolinii DSM 2805 ${ }^{\mathrm{T}}$ (Boone \& Bryant, 1980; Wallrabenstein et al., 1994; Harmsen et al., 1998). -, Negative; +, positive; ND, not determined.

\begin{tabular}{|c|c|c|c|c|c|}
\hline Characteristic & 1 & 2 & 3 & 4 & 5 \\
\hline Cell width $(\mu \mathrm{m})$ & $1 \cdot 0-1 \cdot 3$ & $1 \cdot 25-1 \cdot 5$ & $1 \cdot 1-1 \cdot 6$ & $1 \cdot 0-1 \cdot 2$ & $0 \cdot 6-1 \cdot 0$ \\
\hline Cell length $(\mu \mathrm{m})$ & $1 \cdot 8-2 \cdot 2$ & $1 \cdot 75-2 \cdot 5$ & $1 \cdot 8-2 \cdot 5$ & $2 \cdot 2-3 \cdot 0$ & $1 \cdot 0-4 \cdot 5$ \\
\hline Motility & - & - & - & + & - \\
\hline Gas vacuoles & - & - & - & + & - \\
\hline DNA G $+C$ content $(\mathrm{mol} \%)$ & $58 \cdot 5$ & $56 \cdot 7$ & $60 \cdot 6$ & $57 \cdot 3$ & ND \\
\hline \multicolumn{6}{|l|}{ Growth pH: } \\
\hline Range & $6 \cdot 2-8 \cdot 8$ & $\mathrm{ND}$ & $6 \cdot 0-8 \cdot 0$ & $6 \cdot 2-8 \cdot 0$ & ND \\
\hline Optimum & $7 \cdot 0-7 \cdot 6$ & ND & $7 \cdot 0$ & $7 \cdot 0-7 \cdot 3$ & ND \\
\hline \multicolumn{6}{|l|}{ Growth temperature $\left({ }^{\circ} \mathrm{C}\right)$ : } \\
\hline Range & $20-48$ & $20-42$ & $20-40$ & $20-37$ & ND \\
\hline Optimum & 37 & 40 & 37 & 37 & ND \\
\hline \multicolumn{6}{|l|}{ Utilization in pure culture of: } \\
\hline Lactate & - & - & - & + & ND \\
\hline Fumarate & - & ND & + & - & + \\
\hline Pyruvate & + & ND & + & - & + \\
\hline \multicolumn{6}{|l|}{ Utilization in co-culture with methanogens of: } \\
\hline Lactate & - & ND & - & + & ND \\
\hline Propanol & - & ND & - & + & ND \\
\hline Growth rate on propionate plus sulfate $\left(\right.$ day $\left.^{-1}\right)$ & $0 \cdot 12$ & ND & $0 \cdot 024$ & $0 \cdot 07$ & $0 \cdot 062$ \\
\hline
\end{tabular}

monoculture, but also in methanogenic co-culture. All these features were not shared by strains $\mathrm{TB}^{\mathrm{T}} 106^{\mathrm{T}}$ and WZH410. Furthermore, strains TB8106 ${ }^{\mathrm{T}}$ and WZH410 had obviously higher growth rates on propionate plus sulfate $\left(0 \cdot 12\right.$ day $\left.^{-1}\right)$ than Syntrophobacter fumaroxidans DSM $10017^{\mathrm{T}}\left(0 \cdot 024 \mathrm{day}^{-1}\right)$. In addition, the novel isolates grew well at $48{ }^{\circ} \mathrm{C}$ and $\mathrm{pH} 8 \cdot 8$, a higher growth temperature and $\mathrm{pH}$ than those for other members of the genus Syntrophobacter. DNA-DNA hybridization between strain TB8106 $^{\mathrm{T}}$ and Syntrophobacter fumaroxidans DSM $10017^{\mathrm{T}}$ showed a low genome DNA-DNA relatedness $(12 \cdot 5 \%)$, indicating that they belong to different species.

On the basis of the morphological and physiological differences, 16S rRNA gene sequence divergency and lower DNA-DNA relatedness between the strains described in this report and other members of the genus Syntrophobacter, we propose that strains TB $8106^{\mathrm{T}}$ and WZH410 should be classified as representing a novel species, for which the name Syntrophobacter sulfatireducens sp. nov. is proposed.

The description of the genus Syntrophobacter of Boone \& Bryant (1980) indicated that sulfate did not serve as an electron acceptor in the energy metabolism. However, the later-described syntrophic propionate-degrading species
Syntrophobacter fumaroxidans, Syntrophobacter pfennigii and the novel isolates in this work were all demonstrated to be capable of coupling propionate oxidation to sulfate reduction. In addition, Syntrophobacter wolinii was also shown to be able to use sulfate as an electron acceptor (Wallrabenstein et al., 1994). Hence, it is necessary to emend the description of the genus to emphasize the sulfate reduction capability, in accordance with its close phylogenetic relationship with sulfate reducers.

\section{Emended description of the genus Syntrophobacter}

The description is based on the phenotypic data of Boone \& Bryant (1980), Wallrabenstein et al. (1994, 1995) and Harmsen et al. (1998).

Gram-negative, non-motile, rod- to egg-shaped cells. Endospores are not formed. Strictly anaerobic chemoorganotrophs. Mesophilic. Growth by fermentation or by reduction of sulfate to sulfide. Pure cultures oxidize propionate with sulfate as the electron acceptor. Propionate is fermented syntrophically to acetate and $\mathrm{CO}_{2}$ in the presence of hydrogen- and/or formate-utilizing methanogens (e.g. Methanospirillum hungatei). The $\mathrm{G}+\mathrm{C}$ content of the genomic DNA is $56 \cdot 7-60 \cdot 6 \mathrm{~mol} \%$. 
The type species is Syntrophobacter wolinii.

\section{Description of Syntrophobacter sulfatireducens sp. nov.}

Syntrophobacter sulfatireducens (sul' fa'ti.re.du'cens. N.L. n. sulfas -atis, sulfate; L. v. reducere to lead back, bring back; N.L. part. adj. sulfatireducens reducing sulfate).

Morphology and general characteristics are as described for the genus. Egg-shaped cells, $1 \cdot 0-1 \cdot 3 \times 1 \cdot 8-2 \cdot 2 \mu \mathrm{m}$ in size, single, in pairs or in chains. Pure cultures oxidize propionate and pyruvate to acetate, with sulfate as electron acceptor; pyruvate is also oxidized by fermentation. Does not grow on $\mathrm{H}_{2} / \mathrm{CO}_{2}$, formate, $\mathrm{H}_{2}$ plus fumarate, formate plus fumarate, acetate, butyrate, crotonate, succinate, fumarate, oxaloacetate, malate, citrate, malonic acid, glutarate, alanine, glycine, asparagine, benzoate, methanol, ethanol, 1-propanol or 1-butanol. Sulfate and thiosulfate are both used as electron acceptors, but sulfur, nitrate and fumarate are not reduced. Growth is optimal at $\mathrm{pH} 7 \cdot 0-7 \cdot 6$ and at $37^{\circ} \mathrm{C}$. The $\mathrm{G}+\mathrm{C}$ content of genomic DNA is $58.5-58.7 \mathrm{~mol} \%$. Habitat is granular sludge of UASB reactors.

The type strain is $\mathrm{TB} 106^{\mathrm{T}}\left(=\mathrm{AS} 1.5016^{\mathrm{T}}=\mathrm{DSM} 16706^{\mathrm{T}}\right)$, which was isolated from a UASB reactor treating brewery wastewater, in Beijing, China.

\section{Acknowledgements}

The research was supported by the National Basic Research Program of China (2004CB719602) and NSFC (30025001).

\section{References}

Boone, D. R. \& Bryant, M. (1980). Propionate-degrading bacterium Syntrophobacter wolinii sp. nov. gen. nov., from methanogenic ecosystems. Appl Environ Microbiol 40, 626-632.

Chen, S. \& Dong, X. (2004). Acetanaerobacterium elongatum gen. nov., sp. nov., from paper mill waste water. Int J Syst Evol Microbiol 54, 2257-2262.

de Bok, F. A. M., Stams, A. J. M., Dijkema, C. \& Boone, D. R. (2001). Pathway of propionate oxidation by a syntrophic culture of Smithella propionica and Methanospirillum hungatei. Appl Environ Microbiol 67, 1800-1804.

De Ley, J., Cattoir, H. \& Reynaerts, A. (1970). The quantitative measurement of DNA hybridization from renaturation rates. Eur J Biochem 12, 133-142.

Felsenstein, J. (1985). Confidence limits on phylogenies: an approach using the bootstrap. Evolution 39, 783-791.

Felsenstein, J. (1993). PHYLIP (phylogeny inference package), version 3.5c. Department of Genetics, University of Washington, Seattle, USA.

Harmsen, H. J. M., Wullings, B., Akkermans, A. D. L., Ludwig, W. \& Stams, A. J. M. (1993). Phylogenetic analysis of Syntrophobacter wolinii reveals a relationship with sulfate-reducing bacteria. Arch Microbiol 160, 238-240.
Harmsen, H. J. M., Kuijk, B. L. M., Plugge, C. M., Akkermans, A. D. L., De Vos, W. M. \& Stams, A. J. M. (1998). Syntrophobacter fumaroxidans sp. nov., a syntrophic propionate- degrading sulfatereducing bacterium. Int J Syst Bacteriol 48, 1383-1387.

Holdeman, L. V., Cato, E. P. \& Moore, W. E. C. (1977). Anaerobe Laboratory Manual, 4th edn. Blacksburg, VA: Virginia Polytechnic Institute and State University.

Houwen, F. P., Plokker, J., Stams, A. J. M. \& Zehnder, A. J. B. (1990). Enzymatic evidence for involvement of the methyl-malonyl-CoA pathway in propionate oxidation by Syntrophobacter wolinii. Arch Microbiol 155, 52-55.

Hungate, R. E. (1969). A roll tube method for cultivation of strict anaerobes. Methods Microbiol 3B, 117-132.

Imachi, H., Sekiguchi, Y., Kamagata, Y., Hanada, S., Ohashi, A. \& Harada, H. (2002). Pelotomaculum thermopropionicum gen. nov., sp. nov., an anaerobic, thermophilic, syntrophic propionate-oxidizing bacterium. Int $J$ Syst Evol Microbiol 52, 1729-1735.

Kumar, S., Tamura, K., Jakobsen, I. B. \& Nei, M. (2001). MEGA2: molecular evolutionary genetics analysis software. Bioinformatics 17, 1244-1245.

Liu, Y., Balkwill, D. L., Aldrich, H. C., Drake, G. R. \& Boone, D. R. (1999). Characterization of the anaerobic propionate-degrading syntrophs Smithella propionica gen. nov., sp. nov. and Syntrophobacter wolinii. Int J Syst Bacteriol 49, 545-556.

Marmur, J. (1961). A procedure for the isolation of deoxyribonucleic acid from microorganisms. J Mol Biol 3, 208-218.

Marmur, J. \& Doty, P. (1962). Determination of the base composition of deoxyribonucleic acid from its thermal denaturation temperature. J Mol Biol 5, 109-118.

Nilsen, R. K., Torsvik, T. \& Lien, T. (1996). Desulfotomaculum thermocisternum sp. nov., a sulfate reducer isolated from a hot North sea oil reservoir. Int J Syst Bacteriol 46, 397-402.

Plugge, C. M., Dijkema, C. \& Stams, A. J. M. (1993). Acetyl-CoA cleavage pathway in a syntrophic propionate oxidizing bacterium growing on fumarate in the absence of methanogens. FEMS Microbiol Lett 110, 71-76.

Plugge, C. M., Balk, M. \& Stams, A. J. M. (2001). Desulfotomaculum thermobenzoicum subsp. thermosyntrophicum subsp. nov., a thermophilic, syntrophic, propionate-oxidizing, spore-forming bacterium. Int J Syst Evol Microbiol 52, 391-399.

Schink, B. (1997). Energetics of syntrophic cooperation in methanogenic degradation. Mol Biol Rev 61, 262-280.

Stams, A. J. M. (1994). Metabolic interactions between anaerobic bacteria in methanogenic environments. Antonie van Leeuwenhoek 66, 271-294.

Stams, A. J. M., Grolle, K. C. F., Frijters, C. T. M. \& Van Lier, J. B. (1992). Enrichment of thermophilic propionate-oxidizing bacteria in syntrophy with Methanobacterium thermoautotrophicum or Methanobacterium thermoformicicum. Appl Environ Microbiol 58, 346-352.

Thompson, J. D., Gibson, T. J., Plewniak, F., Jeanmougin, F. \& Higgins, D. G. (1997). The CLUSTAL_X Windows interface: flexible strategies for multiple sequence alignment aided by quality analysis tools. Nucleic Acids Res 24, 4876-4882.

Wallrabenstein, C., Hauschild, E. \& Schink, B. (1994). Pure culture and cytological properties of Syntrophobacter wolinii. FEMS Microbiol Lett 123, 249-254.

Wallrabenstein, C., Hauschild, E. \& Schink, B. (1995). Syntrophobacter pfennigii sp. nov. new syntrophically propionateoxidizing anaerobe growing in pure culture with propionate and sulfate. Arch Microbiol 164, 346-352. 
Zehnder, A. J. B. (1978). Ecology of methane formation. In Water Pollution Microbiology, pp. 349-376. Edited by R. Mitchell. New York: Wiley.
Zellner, G., Busmann, A., Rainey, F. A. \& Diekmann, H. (1996). A syntrophic propionate-oxidizing, sulfate-reducing bacterium from a fluidized bed reactor. Syst Appl Microbiol 19, 414-420. 